\title{
Parasites of domestic and wild animals in South Africa. XLIX. Ticks (Acari: Ixodidae) infesting white and black rhinoceroses in southern Africa
}

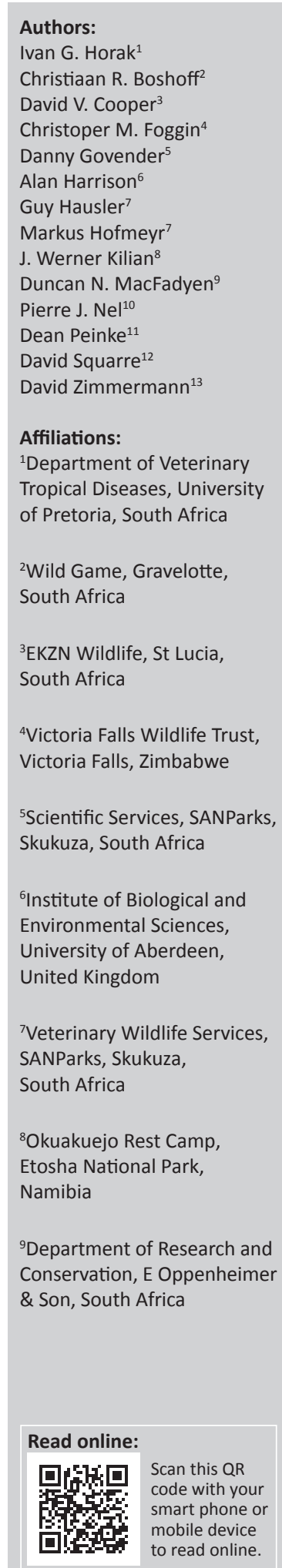

\begin{abstract}
The objectives of the study were to determine the species composition of ticks infesting white and black rhinoceroses in southern Africa as well as the conservation status of those tick species that prefer rhinos as hosts. Ticks were collected opportunistically from rhinos that had been immobilised for management purposes, and 447 white rhinoceroses (Ceratotherium simum) and 164 black rhinoceroses (Diceros bicornis) were sampled in South Africa, 61 black rhinos in Namibia, 18 white and 12 black rhinos in Zimbabwe, and 24 black rhinos in Zambia. Nineteen tick species were recovered, of which two species, Amblyomma rhinocerotis and Dermacentor rhinocerinus, prefer rhinos as hosts. A. rhinocerotis was collected only in the northeastern KwaZulu-Natal reserves of South Africa and is endangered, while D. rhinocerinus is present in these reserves as well as in the Kruger National Park and surrounding conservancies. Eight of the tick species collected from the rhinos are ornate, and seven species are regularly collected from cattle. The species present on rhinos in the eastern, moister reserves of South Africa were amongst others Amblyomma hebraeum, A. rhinocerotis, D. rhinocerinus, Rhipicephalus maculatus, Rhipicephalus simus and Rhipicephalus zumpti, while those on rhinos in the Karoo and the drier western regions, including Namibia, were the drought-tolerant species, Hyalomma glabrum, Hyalomma rufipes, Hyalomma truncatum and Rhipicephalus gertrudae. The species composition of ticks on rhinoceroses in Zambia differed markedly from those of the other southern African countries in that Amblyomma sparsum, Amblyomma tholloni and Amblyomma variegatum accounted for the majority of infestations.
\end{abstract}

\section{Introduction}

Historically white rhinoceroses (Ceratotherium simum) were present from South Africa in the south to the coastal regions of north-eastern Africa in the north (Skinner \& Chimimba 2005). However, with the arrival of European settlers in southern Africa, as well as hunters, naturalists and travellers, the numbers of white rhinos in this region rapidly dwindled. Towards the end of the 19th century the last white rhinos were shot in Zimbabwe and Botswana, while in South Africa their numbers had declined to approximately 20-50 animals in north-eastern KwaZulu-Natal. The proclamation of the Hluhluwe and Imfolozi Game Reserves in 1895 and the Mkuze Game Reserve in 1912 in KwaZulu-Natal is considered to have rescued them from extinction in South Africa (Skinner \& Chimimba 2005). Their numbers have steadily increased since then and in 1961 the Natal Parks Board initiated a project on the relocation of rhinoceroses from the reserves under its control to the Kruger National Park and other state and provincially controlled reserves, as well as to privately owned reserves lying within the rhinos' former distribution range. Although the number of white rhinos in South Africa now exceeds 18 000, the ever-increasing rate at which they are being poached may soon surpass their birth rate.

The numbers of black rhinoceroses (Diceros bicornis) declined as rapidly as those of white rhinoceroses. From a situation in which they were present on the slopes of Table Mountain in 1652, to where the proclamation of the Hluhluwe, Imfolozi and Mkuze game reserves in

\footnotetext{
${ }^{10}$ Department of Economic Development, Tourism and Environmental Affairs, Bloemfontein, South Africa

${ }^{11}$ Eastern Cape Parks \& Tourism Agency, East London, South Africa

${ }^{12}$ Wildlife Veterinary Unit, Zambia Wildlife Authority, Zambia

${ }^{13}$ Veterinary Wildlife Services, SANParks, Port Elizabeth, South Africa

Corresponding author: Ivan Horak, ivan.horak@up.ac.za

Dates: Received: 22 June 2016 | Accepted: 05 Aug. 2016| Published: 30 Jan. 2017

How to cite this article: Horak, I.G., Boshoff, C.R., Cooper, D.V., Foggin, C.M., Govender, D., Harrison, A. et al., 2017, 'Parasites of domestic and wild animals in South Africa. XLIX. Ticks (Acari: Ixodidae) infesting white and black rhinoceroses in southern Africa', Onderstepoort Journal of Veterinary Research 84(1), a1301. https://doi.org/10.4102/ojvr.v84i1.1301

Copyright: ( 2017 . The Authors. Licensee: AOSIS. This work is licensed under the Creative Commons Attribution License.
} 
KwaZulu-Natal rescued them from extinction in this country (Skinner \& Chimimba 2005). Numbers on the continent are believed to have declined from approximately 100000 in the early 1960 s to only 2410 in 1995 . Since then careful management and relocations have seen their numbers on the continent increase to 4880 by the end of 2010 (Cumming, Du Toit \& Stuart 1990; Knight, Balfour \& Emslie 2013), with most present in the north-eastern KwaZulu-Natal reserves, the Kruger National Park and the Etosha National Park.

Both rhinoceros species are infested with a greater array of ornate ixodid ticks than any other mammal species in East and southern Africa. Most of these are brightly coloured members of the genus Amblyomma, and include Amblyomma eburneum, Amblyomma gemma, Amblyomma hebraeum, Amblyomma personatum, Amblyomma rhinocerotis, Amblyomma sparsum, Amblyomma tholloni and Amblyomma variegatum. Rhinos also harbour Dermacentor rhinocerinus, an ornate tick that is for all practical purposes a specific parasite of these animals. They are also infested by three of the four Rhipicephalus species that are ornate, Rhipicephalus humeralis, Rhipicephalus maculatus and Rhipicephalus pulchellus.

A number of tick surveys conducted in Africa have included rhinoceroses amongst various other animal species sampled. Collections made from black rhinoceroses in Tanzania yielded 18 tick species, including six species in the genus Amblyomma as well as D. rhinocerinus, and two ornate Rhipicephalus spp. (Yeoman \& Walker 1967). Twenty-one tick species were identified in collections from black rhinoceroses in Kenya; these included seven Amblyomma spp., D. rhinocerinus and three ornate Rhipicephalus spp. (Walker 1974). Ten tick species were present in collections made from white and black rhinoceroses in Zimbabwe, and three Amblyomma spp. and D. rhinocerinus were recovered (Norval 1983; Norval \& Colborne 1985). In a checklist of ticks that infest large mammals in the KwaZulu-Natal reserves in South Africa, 11 species were reported on rhinoceroses, these included three Amblyomma spp. (one of them doubtful), D. rhinocerinus and R. maculatus (Baker \& Keep 1970). Collections from two white and four black rhinoceroses sampled at various localities in South Africa yielded nine tick species, including A. hebraeum, D. rhinocerinus and R. maculatus (Knapp et al. 1997).

It is generally not realised that should rhinoceroses go extinct, a multitude of smaller creatures will also disappear. Amongst these are the rhinoceros-specific ticks, A. personatum, A. rhinocerotis, Cosmiomma hippopotamensis and D. rhinocerinus, the flies Rhinomusca dutoiti, Rhinomusca brucei and Gyrostigma rhinocerontis, as well as a horde of rhinospecific nematodes and an even greater number of commensal protozoal species. The extinction of rhinos will thus destroy a whole ecosystem of parasites and commensals.

With the exception of the study by Knapp et al. (1997), no surveys devoted solely to rhinoceroses and the ticks that infest them have been conducted in southern Africa. The objective of the present investigation is to address this shortcoming. As a consequence, a number of surveys aimed at determining the species composition of ticks that infest these animals in the sub-continent were initiated.

\section{Methods}

Participants in the study collected ticks opportunistically from rhinoceroses immobilised for management purposes. Particular attention was paid to the ears, the axilla, inner thighs, peri-anal region and the tail brush. Although this collection procedure represented the ideal, any ticks collected from rhinos were included in the study. More detailed or complete collections were not possible because of the time these would take, causing additional anaesthetic stress on the animals. Ticks collected from each rhino were placed in separate bottles or plastic vials containing 70\% ethyl alcohol or undiluted methylated spirits. A label written in pencil, indicating the rhino's species, its name or identity (if known), gender, the date, the locality at which it was immobilised and the identity of the person responsible for collecting ticks, was placed with the ticks in the bottle or vial. This was not always possible, and several labels were attached to the outside of the containers. The ticks were identified and counted using a stereoscopic microscope.

The identities and total numbers of adult ticks collected from white and black rhinoceroses across southern Africa are summarised in tabular format. They are also tabulated according to the regions in which they were collected from rhinos within South Africa. A separate table has been created for ticks collected in Namibia, Zimbabwe and Tanzania. The regional distributions of the 19 tick species collected from rhinoceroses in southern Africa are represented in a mosaic format.

The conservation status of the ticks that prefer rhinos as hosts and the introduction of ticks into non-endemic habitats or reintroduction into endemic habitats are discussed, as is the role of rhinos as maintenance hosts of ticks that are vectors of diseases of domestic livestock or wildlife species.

\section{Ethical considerations}

No rhinos were immobilised for the sole purpose of collecting ticks. Collection was incidental to other management procedures necessitating immobilisation.

\section{Results \\ South Africa}

The tick species recovered from a total of 465 white and 261 black rhinoceroses across southern Africa, and the number of animals infested with each species are summarised in Table 1. Twelve tick species, including the nymphs of Rhipicephalus appendiculatus, were collected from white rhinoceroses, with A. hebraeum present in the majority of collections, followed by D. rhinocerinus, Hyalomma truncatum and Hyalomma rufipes. Sixteen species were recovered from black rhinoceroses, and A. hebraeum was the most commonly 
TABLE 1: Ixodid ticks collected from white and black rhinoceroses in southern Africa.

\begin{tabular}{|c|c|c|c|c|c|c|}
\hline \multirow[t]{2}{*}{ Ticks collected from rhinoceroses } & \multirow[t]{2}{*}{ Tick species } & \multirow[t]{2}{*}{ Number infested } & \multirow[t]{2}{*}{$\%$ infested } & \multicolumn{3}{|c|}{ Number of ticks recovered } \\
\hline & & & & Males & Females & Total \\
\hline \multicolumn{7}{|l|}{ South Africa and Zimbabwe } \\
\hline \multirow[t]{11}{*}{ White rhinoceroses $(n=465)$} & Amblyomma hebraeum & 382 & 82.2 & 1797 & 1474 & 3271 \\
\hline & Amblyomma rhinocerotis & 8 & 1.7 & 11 & 7 & 18 \\
\hline & Amblyomma tholloni & 3 & 0.6 & 1 & 2 & 3 \\
\hline & Dermacentor rhinocerinus & 153 & 32.9 & 478 & 112 & 590 \\
\hline & Hyalomma rufipes & 71 & 15.3 & 218 & 59 & 277 \\
\hline & Hyalomma truncatum & 86 & 18.5 & 244 & 89 & 333 \\
\hline & Rhipicephalus evertsi evertsi & 3 & 0.6 & 2 & 3 & 5 \\
\hline & Rhipicephalus follis & 5 & 1.1 & 19 & 8 & 27 \\
\hline & Rhipicephalus gertrudae & 7 & 1.5 & 3 & 12 & 15 \\
\hline & Rhipicephalus maculatus & 17 & 3.7 & 234 & 116 & 350 \\
\hline & Rhipicephalus simus & 27 & 5.8 & 50 & 56 & 106 \\
\hline \multicolumn{7}{|c|}{ South Africa, Namibia, Zimbabwe and Zambia } \\
\hline \multirow{14}{*}{ Black rhinoceroses $(n=261)$} & Amblyomma hebraeum & 141 & 54.0 & 847 & 528 & 1375 \\
\hline & Amblyomma rhinocerotis & 3 & 1.1 & 7 & 5 & 12 \\
\hline & Amblyomma sparsum & 23 & 8.8 & 88 & 60 & 148 \\
\hline & Amblyomma tholloni & 15 & 5.7 & 18 & 15 & 33 \\
\hline & Amblyomma variegatum & 14 & 5.4 & 58 & 23 & 81 \\
\hline & Dermacentor rhinocerinus & 10 & 3.8 & 36 & 10 & 46 \\
\hline & Hyalomma glabrum & 4 & 1.5 & 8 & 1 & 9 \\
\hline & Hyalomma rufipes & 96 & 36.8 & 312 & 151 & 463 \\
\hline & Hyalomma truncatum & 75 & 28.7 & 516 & 266 & 782 \\
\hline & Rhipicephalus follis & 19 & 7.3 & 67 & 47 & 114 \\
\hline & Rhipicephalus gertrudae & 9 & 3.4 & 38 & 14 & 52 \\
\hline & Rhipicephalus longiceps & 1 & 0.4 & 0 & 1 & 1 \\
\hline & Rhipicephalus maculatus & 10 & 3.8 & 121 & 54 & 175 \\
\hline & Rhipicephalus neumanni & 2 & 0.8 & 0 & 2 & 2 \\
\hline
\end{tabular}

collected tick, followed by H. rufipes and H. truncatum. The two rhino species harboured ten tick species in common.

The species and numbers of ticks collected from 303 white rhinoceroses in the Kruger National Park and surrounding conservancies and from nine black rhinoceroses in the park, as well as those collected from 49 white rhinos and 20 black rhinos in the north-eastern KwaZulu-Natal reserves, are summarised in Table 2 and the regions in which the ticks were collected are represented in Figure 1. Five species were collected from white rhinos and four from black rhinos in the Kruger National Park. Amblyomma hebraeum was present in the majority of collections made from either rhino species, followed by $D$. rhinocerinus. Three white rhinos were infested with A. tholloni, a tick whose adults prefer elephants as hosts.

Five tick species were recovered from the white rhinos in the KwaZulu-Natal reserves and six from the black rhinos. Amblyomma hebraeum was present in the majority of collections followed by $R$. maculatus on both white and black rhinos, while some animals of both species were infested with the rhinoceros specific ticks $A$. rhinocerotis and D. rhinocerinus (Figure 1).

The tick species collected from rhinoceroses in the Free State, Northern Cape province, North West province, western Limpopo province, and the central and south-eastern region of the Limpopo province and north-eastern Gauteng are summarised in Table 3. Hyalomma rufipes and H. truncatum were the most frequently collected ticks from both rhino species in the Free State and Northern Cape. The collections of $A$. hebraeum from white rhinoceroses in the Free State were made from animals that had recently been introduced into the province from regions in which the tick was present and do not represent established populations. Most white rhinos in eastern North West province and western Limpopo province were infested with $A$. hebraeum, and it was the only species collected from black rhinoceroses.

Ticks were also collected from a dead white rhinoceros originating from a reserve in the southern central region of Limpopo province and presented for necropsy at the Faculty of Veterinary Science, Pretoria University, Onderstepoort. Because it was dead, considerably more ticks were collected from it than from other white rhinos that were temporarily immobilised. Ticks were also collected from eight white rhinos in the south-eastern region of Limpopo province and two animals in north-eastern Gauteng. We consider all these animals to have come from the central region of two of the northern provinces of South Africa and the numbers and species of ticks collected from them are summarised in Table 3. In addition to A. hebraeum and H. rufipes, they harboured Rhipicephalus evertsi evertsi and Rhipicephalus follis and the dead animal was infested with a large number of 
TABLE 2: Ixodid ticks collected from rhinoceroses in the Kruger National Park and surrounding conservancies, and in the north-eastern KwaZulu-Natal reserves.

\begin{tabular}{|c|c|c|c|c|c|c|}
\hline \multirow[t]{2}{*}{ Ticks collected from rhinoceroses } & \multirow[t]{2}{*}{ Tick and host species } & \multirow[t]{2}{*}{ Number infested } & \multirow[t]{2}{*}{$\%$ infested } & \multicolumn{3}{|c|}{ Number of ticks recovered } \\
\hline & & & & Males & Females & Total \\
\hline \multicolumn{7}{|c|}{ Kruger National Park and surrounding conservancies } \\
\hline \multirow[t]{4}{*}{ White rhinoceroses $(n=303)$} & Amblyomma hebraeum & 294 & 97.0 & 1180 & 957 & 2137 \\
\hline & Amblyomma tholloni & 3 & 1.0 & 1 & 2 & 3 \\
\hline & Dermacentor rhinocerinus & 145 & 47.0 & 428 & 96 & 524 \\
\hline & Hyalomma truncatum & 31 & 10.0 & 41 & 15 & 56 \\
\hline \multirow[t]{4}{*}{ Black rhinoceroses $(n=9)$} & Amblyomma hebraeum & 9 & 100.0 & 33 & 24 & 57 \\
\hline & Dermacentor rhinocerinus & 6 & 66.7 & 10 & 3 & 13 \\
\hline & Hyalomma truncatum & 1 & 0.3 & 1 & 0 & 1 \\
\hline & Rhipicepalus simus & 1 & 11.1 & 3 & 0 & 3 \\
\hline \multicolumn{7}{|c|}{ North-eastern KwaZulu-Natal reserves } \\
\hline \multirow[t]{4}{*}{ White rhinoceroses $(n=49)$} & Amblyomma hebraeum & 49 & 100.0 & 273 & 267 & 540 \\
\hline & Amblyomma rhinocerotis & 8 & 16.3 & 11 & 7 & 18 \\
\hline & Rhipicephalus maculatus & 17 & 34.7 & 234 & 116 & 350 \\
\hline & Rhipicepalus simus & 5 & 10.2 & 3 & 3 & 6 \\
\hline \multirow[t]{6}{*}{ Black rhinoceroses $(n=20)$} & Amblyomma hebraeum & 19 & 95.0 & 108 & 97 & 205 \\
\hline & Amblyomma rhinocerotis & 3 & 15.0 & 7 & 5 & 12 \\
\hline & Dermacentor rhinocerinus & 4 & 20.0 & 26 & 7 & 33 \\
\hline & Hyalomma truncatum & 1 & 5.0 & 1 & 0 & 1 \\
\hline & Rhipicephalus maculatus & 10 & 50.0 & 121 & 54 & 175 \\
\hline & Rhipicepalus simus & 2 & 10.0 & 2 & 1 & 3 \\
\hline
\end{tabular}

Rhipicephalus simus. Three of the eleven animals were infested with seven nymphs of R. appendiculatus.

The species and numbers of ticks collected from rhinoceroses in the Great Fish River Nature Reserve and the Addo Elephant National Park in the Eastern Cape province, and the Mountain Zebra and the Karoo National Parks are summarised in Table 4. All but one of the black rhinoceroses examined in the Eastern Cape province were infested with A. hebraeum, and a substantial number of collections of $R$. follis and particularly $R$. simus were also made. The rather rare species, Rhipicephalus zumpti, was also present. Four of the black rhinoceroses examined in the Mountain Zebra and Karoo National Parks were infested with Hyalomma glabrum and five with $H$. truncatum and $R$. follis.

\section{Namibia}

The tick species collected from black rhinoceroses in three regions of Namibia are summarised in Table 5. The rhinos in the Etosha National Park were infested with H. rufipes and $H$. truncatum, the Damaraland rhinos with $H$. rufipes and one animal with the very rare Rhipicephalus longiceps, while the rhinos in the Hardap Nature Reserve harboured H. rufipes, $H$. truncatum and Rhipicephalus gertrudae, an assemblage of ticks fairly similar to that on white and black rhinoceroses in the Free State and Northern Cape provinces (Figure 1).

\section{Zimbabwe}

The results of collections from rhinos in the Malilangwe reserve in south-eastern Zimbabwe are summarised in Table 5. All the animals were infested with $A$. hebraeum. A single collection of $A$. tholloni was made from a black rhinoceros.

\section{Zambia}

The tick species present on black rhinoceroses examined in the North Luangwa National Park in Northern province differed substantially from those of the other southern African animals (Table 5). Amblyomma sparsum was the dominant species with all but one animal being infested. A number of collections of $A$. tholloni and A. variegatum were also made (Figure 1). The Zambian rhinos had originally come from the Kruger National Park, Marakele National Park and the KwaZulu-Natal and Eastern Cape parks.

\section{Discussion}

\section{Amblyomma gemma}

The only rhinos infested with $A$. gemma were those examined in Zambia (Figure 1). Neither Theiler (1962) nor Walker and Olwage (1987) include Zambia within the distribution range of A. gemma. In neighbouring Tanzania, its distribution is almost entirely limited to semi-arid bush and thicket and by rainfall between $38 \mathrm{~mm}$ and $76 \mathrm{~mm}$, with a few records close to the north-eastern border of Zambia (Yeoman \& Walker 1967). Its collection now from a black rhinoceros in Northern province, Zambia is possibly a new locality record.

The preferred hosts of the adults of A. gemma are large domestic and wild herbivores (Theiler 1962; Walker 1974; Yeoman \& Walker 1967). Yeoman and Walker (1967) record collections from four of eight rhinoceroses examined in Tanzania, and Walker (1974) reports collections from 28 of 54 black rhinoceroses sampled in Kenya. Considering that only one of the 24 rhinoceroses examined in Zambia was infested, it may imply that the distribution of $A$. gemma in northern Zambia is tenuous, or that collections were made 


\begin{tabular}{|c|c|c|c|c|c|c|c|c|c|c|}
\hline \multirow{2}{*}{ Tick species } & \multicolumn{10}{|c|}{ Regions } \\
\hline & KNP & KZN & CNP & NW & FS/NC & EC & KAROO & NAM & ZIM & ZAM \\
\hline \multicolumn{11}{|l|}{ Amblyomma gemma } \\
\hline \multicolumn{11}{|c|}{ Amblyomma hebraeum } \\
\hline \multicolumn{11}{|c|}{ Amblyomma rhinocerotis } \\
\hline \multicolumn{11}{|l|}{ Amblyomma sparsum } \\
\hline \multicolumn{11}{|l|}{ Amblyomma tholloni } \\
\hline \multicolumn{11}{|c|}{ Amblyomma variegatum } \\
\hline \multicolumn{11}{|c|}{ Dermacentor rhinocerinus } \\
\hline \multicolumn{11}{|l|}{ Hyalomma glabrum } \\
\hline \multicolumn{11}{|l|}{ Hyalomma rufipes } \\
\hline \multicolumn{11}{|l|}{ Hyalomma truncatum } \\
\hline \multicolumn{11}{|c|}{ Rhipicephalus appendiculatus } \\
\hline \multicolumn{11}{|l|}{ Rhipicephalus evertsi } \\
\hline \multicolumn{11}{|l|}{ Rhipicephalus follis } \\
\hline \multicolumn{11}{|c|}{ Rhipicephalus gertrudae } \\
\hline \multicolumn{11}{|c|}{ Rhipicephalus longiceps } \\
\hline \multicolumn{11}{|c|}{ Rhipicephalus maculatus } \\
\hline \multicolumn{11}{|c|}{ Rhipicephalus neumanni } \\
\hline \multicolumn{11}{|l|}{ Rhipicephalus simus } \\
\hline Rhipicephalus zumpti & & & & & & & & & & \\
\hline
\end{tabular}

KNP, Kruger National Park; KZN, KwaZulu-Natal province; CNP, Central Northern provinces; NW, North western region; FS/NC, Free State/Northern Cape provinces; EC, Eastern Cape province; NAM, Namibia; ZIM, Zimbabwe; ZAM, Zambia.

FIGURE 1: The regional distribution of ticks that infest rhinoceroses in southern Africa.

during the wrong season. Nymphs have been recovered from helmeted guineafowls and Cape hares (Yeoman \& Walker 1967).

\section{Amblyomma hebraeum}

Amblyomma hebraeum is present along the southern and eastern seaboard of South Africa, from approximately Port Elizabeth in the west to southern Mozambique in the east. It also occurs in the northern provinces of South Africa, south-eastern Botswana, and southern and north-western Zimbabwe (Walker \& Olwage 1987). The collections from rhinos in the north-eastern, eastern and south-eastern regions of South Africa and south-east Zimbabwe (Figure 1) all lie within its known geographical distribution range (Norval 1983; Spickett 2013; Walker \& Olwage 1987). It has been introduced into the Grassland biome of Free State province on white rhinoceroses but is unlikely to survive there (Horak et al. 2015). However, should it be introduced into the Savanna biome in the north of the same province its establishment there is a distinct possibility.
The adults of this brightly coloured tick infest cattle, sheep and goats as well as the larger wildlife species, while its immature stages infest the same hosts as the adults, but also hares, the larger ground frequenting birds and tortoises (Dower, Petney \& Horak 1988; Horak, Golezardy \& Uys 2007; Horak et al. 1987). In Zimbabwe, Norval (1983) recorded A. hebraeum in 15 of 19 tick collections made from white rhinoceroses, and in the present survey the 30 rhinoceroses examined in that country were all infested. The large proportion of rhinos that were infested in most of the regions in which A. hebraeum occurs, as well as the large numbers of adult ticks that have been collected from rhinos when total collections were made (Knapp et al. 1997), is a clear indication that rhinos must be considered as one of the preferred hosts of this species.

Amblyomma hebraeum is the most effective vector of Ehrlichia ruminatium, the causative organism of heartwater in cattle, sheep and goats and some wildlife species (Norval \& Horak 2004). It is also the vector of Rickettsia africae, the causative organism of African tick bite fever in humans (Kelly 2001). 
TABLE 3: Ixodid ticks collected from rhinoceroses in the Free State, Northern Cape province, north-western parks and central region of two northern provinces of South Africa.

\begin{tabular}{|c|c|c|c|c|c|c|}
\hline \multirow[t]{2}{*}{ Ticks collected from rhinoceroses } & \multirow[t]{2}{*}{ Tick and host species } & \multirow[t]{2}{*}{ Number infested } & \multirow[t]{2}{*}{$\%$ infested } & \multicolumn{3}{|c|}{ Number of ticks recovered } \\
\hline & & & & Males & Females & Total \\
\hline \multicolumn{7}{|c|}{ Central region of the northern provinces } \\
\hline \multirow[t]{6}{*}{ White rhinoceroses $(n=11)$} & Amblyomma hebraeum & 8 & 72.7 & 183 & 193 & 376 \\
\hline & Hyalomma rufipes & 6 & 54.5 & 18 & 2 & 20 \\
\hline & Hyalomma truncatum & 1 & 9.1 & 1 & 0 & 1 \\
\hline & Rhipicephalus eversti evertsi & 2 & 18.2 & 2 & 2 & 4 \\
\hline & Rhipicephalus follis & 4 & 36.4 & 6 & 5 & 11 \\
\hline & Rhipicephalus simus & 2 & 18.2 & 20 & 36 & 56 \\
\hline \multicolumn{7}{|l|}{ North-western parks of South Africa } \\
\hline \multirow[t]{3}{*}{ White rhinoceroses $(n=6)$} & Amblyomma hebraeum & 5 & 83.3 & 24 & 13 & 37 \\
\hline & Hyalomma rufipes & 2 & 33.3 & 3 & 1 & 4 \\
\hline & Hyalomma truncatum & 2 & 33.3 & 2 & 0 & 2 \\
\hline Black rhinoceroses $(n=12)$ & Amblyomma hebraeum & 12 & 100.0 & 50 & 19 & 69 \\
\hline \multicolumn{7}{|c|}{ Free State and Northern Cape provinces } \\
\hline \multirow{5}{*}{ White rhinoceroses $(n=78)$} & Hyalomma rufipes & 62 & 79.5 & 194 & 56 & 250 \\
\hline & Hyalomma truncatum & 52 & 66.7 & 200 & 74 & 274 \\
\hline & Rhipicephalus evertsi evertsi & 1 & 1.3 & 0 & 1 & 1 \\
\hline & Rhipicephalus follis & 1 & 1.3 & 13 & 3 & 16 \\
\hline & Rhipicephalus gertrudae & 7 & 9.0 & 3 & 12 & 15 \\
\hline \multirow[t]{5}{*}{ Black rhinoceroses $(n=27)$} & Hyalomma rufipes & 25 & 92.6 & 82 & 30 & 112 \\
\hline & Hyalomma truncatum & 24 & 88.9 & 120 & 61 & 181 \\
\hline & Rhipicephalus follis & 3 & 11.1 & 4 & 1 & 5 \\
\hline & Rhipicephalus gertrudae & 3 & 11.1 & 3 & 2 & 5 \\
\hline & Rhipicephalus neumanni & 2 & 7.4 & 0 & 2 & 2 \\
\hline
\end{tabular}

TABLE 4: Ixodid ticks collected from black rhinoceroses in the Great Fish River Nature Reserve and the Addo Elephant National Park, Eastern Cape province, and the Mountain Zebra and Karoo National Parks.

\begin{tabular}{|c|c|c|c|c|c|c|}
\hline \multirow[t]{2}{*}{ Ticks collected from rhinoceroses } & \multirow[t]{2}{*}{ Tick and host species } & \multirow[t]{2}{*}{ Number infested } & \multirow[t]{2}{*}{$\%$ infested } & \multicolumn{3}{|c|}{ Number of ticks recovered } \\
\hline & & & & Males & Females & Total \\
\hline \multicolumn{7}{|l|}{ Eastern Cape province } \\
\hline \multirow[t]{5}{*}{ Black rhinoceroses $(n=90)$} & Amblyomma hebraeum & 89 & 98.9 & 558 & 344 & 902 \\
\hline & Hyalomma rufipes & 5 & 5.6 & 4 & 2 & 6 \\
\hline & Hyalomma truncatum & 5 & 5.6 & 11 & 11 & 22 \\
\hline & Rhipicephalus follis & 11 & 12.2 & 30 & 26 & 56 \\
\hline & Rhipicephalus zumpti & 2 & 2.2 & 3 & 0 & 3 \\
\hline \multicolumn{7}{|c|}{ Mountain Zebra and Karoo National Parks } \\
\hline \multirow[t]{3}{*}{ Black rhinoceroses $(n=6)$} & Hyalomma glabrum & 4 & 66.7 & 8 & 1 & 9 \\
\hline & Hyalomma truncatum & 5 & 83.3 & 17 & 3 & 20 \\
\hline & Rhipicephalus follis & 5 & 83.3 & 33 & 20 & 53 \\
\hline
\end{tabular}

\section{Amblyomma rhinocerotis}

The first two ticks with a South African origin to be described were Amblyomma rhinocerotis and Amblyomma sylvaticum. Amblyomma rhinocerotis had been collected from a rhinoceros at the Cape of Good Hope and A. sylvaticum from angulate tortoises, and both were described by De Geer in 1778. By all accounts, the adults of $A$. rhinocerotis are host-specific parasites of white and black rhinoceroses, and were probably present on these animals in the coastal and wooded inland regions from Cape Town in the south-west to the Kruger National Park in the north-east of South Africa. However, by the turn of the 19th century A. rhinocerotis and its hosts possibly only survived in the north-eastern region of KwaZulu-Natal, South Africa. Subsequent to the review on the ticks infesting larger wildlife in the KwaZulu-Natal reserves by Baker and Keep in 1970, there have been no reports, until now, of its presence in South Africa.
In Zimbabwe, Duncan (1989) visually estimated that there were between 100 and 500 or more adult $A$. rhinocerotis on 16 of 18 black rhinoceroses prior to their treatment with an acaricide and relocation from the Zambezi Valley to safer habitats in the centre of the country. There have been no subsequent reports of its occurrence in that country. In their review of the ixodid ticks which they believe to be endangered, Mihalca, Gherman and Cozma (2011) regard A. rhinocerotis as 'critically endangered' if black rhinoceroses were its only hosts within a particular region, whereas on white rhinoceroses it is 'near threatened'.

Despite numerous translocations of rhinos from the northeastern KwaZulu-Natal reserves, A. rhinocerotis has failed to become established elsewhere, perhaps because rhinos are treated with an acaricide before translocation. Its precarious survival even in the KwaZulu-Natal reserves is highlighted by the fact that only 11 of the 69 rhinoceroses 
TABLE 5: Ixodid ticks collected from rhinoceroses in Namibia, Zimbabwe and Zambia.

\begin{tabular}{|c|c|c|c|c|c|c|}
\hline \multirow[t]{2}{*}{ Ticks collected from rhinoceroses } & \multirow[t]{2}{*}{ Tick species and hosts } & \multirow[t]{2}{*}{ Number infested } & \multirow[t]{2}{*}{$\%$ infested } & \multicolumn{3}{|c|}{ Number of ticks recovered } \\
\hline & & & & Males & Females & Total \\
\hline \multicolumn{7}{|l|}{ Three localities in Namibia } \\
\hline \multirow[t]{2}{*}{ Black rhinoceroses: Etosha $(n=33)$} & Hyalomma rufipes & 30 & 91.0 & 102 & 59 & 161 \\
\hline & Hyalomma truncatum & 32 & 97.0 & 350 & 183 & 533 \\
\hline \multirow[t]{2}{*}{ Black rhinoceroses: Damaraland $(n=22)$} & Hyalomma rufipes & 22 & 100.0 & 103 & 53 & 156 \\
\hline & Rhipicephallus longiceps & 1 & 4.5 & 1 & 0 & 1 \\
\hline & Hyalomma truncatum & 5 & 83.3 & 14 & 7 & 21 \\
\hline & Rhipicephalus gertrudae & 6 & 100.0 & 35 & 12 & 47 \\
\hline \multicolumn{7}{|l|}{ Zimbabwe } \\
\hline \multirow[t]{2}{*}{ White rhinoceroses $(n=18)$} & Amblyomma hebraeum & 18 & 100.0 & 122 & 33 & 155 \\
\hline & Hyalomma rufipes & 1 & 5.6 & 3 & 0 & 3 \\
\hline \multirow[t]{3}{*}{ Black rhinoceroses $(n=12)$} & Amblyomma hebraeum & 12 & 100.0 & 98 & 44 & 142 \\
\hline & Amblyomma tholloni & 1 & 8.3 & 0 & 1 & 1 \\
\hline & Hyalomma truncatum & 1 & 8.3 & 1 & 0 & 1 \\
\hline \multicolumn{7}{|l|}{ Zambia } \\
\hline \multirow[t]{6}{*}{ Black rhinoceroses $(n=24)$} & Amblyomma gemma & 1 & 4.2 & 3 & 2 & 5 \\
\hline & Amblyomma sparsum & 23 & 95.8 & 88 & 60 & 148 \\
\hline & Amblyomma tholloni & 14 & 58.3 & 18 & 14 & 32 \\
\hline & Amblyomma variegatum & 14 & 58.3 & 58 & 23 & 81 \\
\hline & Hyalomma rufipes & 6 & 25.0 & 8 & 0 & 8 \\
\hline & Hyalomma truncatum & 1 & 4.2 & 1 & 1 & 2 \\
\hline
\end{tabular}

examined there were infested and that only 18 male and 12 female ticks were collected. Not one of the 303 white or 9 black rhinoceroses examined in the Kruger National Park was infested, nor any of the 96 black rhinoceroses in the Eastern Cape and Karoo (Figure 1). Some of the latter animals were examined in the Albany Thicket Biome, a habitat possibly suitable for the survival of the tick. Nor were any of the rhinos examined in Namibia, Zimbabwe or Zambia infested.

\section{Amblyomma sparsum}

Walker and Olwage (1987) have plotted the overall distribution of $A$. sparsum with most records coming from Tanzania and Kenya, some from northern and north-western Zimbabwe and a single record from south-eastern Zambia. According to Theiler and Salisbury (1959), there is an isolated record of A. sparsum from Grootfontein, Namibia. Walker (1991) elaborates on this record, stating that it was a male tick collected by a Government Veterinary Officer in 1933. No subsequent collections have been made, and we now believe A. sparsum to be extinct in Namibia.

The adults of $A$. sparsum infest two remarkably different groups of hosts. The one group comprises tortoises, monitor lizards and the larger species of snakes and the other rhinoceroses and buffaloes (Walker 1974; Yeoman \& Walker 1967). Norval (1983) recorded a total of 619 male and 175 female A. sparsum in collections from 66 black rhinoceroses in north-western Zimbabwe, and Duncan (1989) visually estimated there to be between 10 and 50 ticks on 16 of 18 rhinoceroses he examined in the same region. The collection now of A. sparsum from 23 of 24 black rhinoceroses in North Luangwa National Park, Zambia indicates that it is well established there (Figure 1).
Norval and MacKenzie (1981) successfully transmitted E. ruminantium to sheep by means of $A$. sparsum nymphs that had fed as larvae on an infected sheep. However, transmission via adult ticks that had fed either as larvae or as nymphs on infected sheep, failed.

\section{Amblyomma tholloni}

According to Walker and Olwage (1987), the distribution of A. tholloni is linked to that of its preferred host, the African elephant, Loxodonta africana in southern, East, and Central Africa, as well as in some of the southern countries in West Africa. Sixteen collections of A. tholloni were made from elephants in the Kruger National Park during the present survey, while in Zimbabwe all 29 elephants and 22 of 24 hippopotamuses examined for ticks, were infested (Norval 1983). The recovery of $A$. tholloni from three white rhinoceroses in the Kruger National Park, a single black rhinoceros in Zimbabwe and 14 black rhinoceroses in Zambia, implies that it may use rhinos as alternative hosts to elephants and hippopotamuses. Mihalca et al. (2011) list A. tholloni as coendangered with its elephant hosts as 'vulnerable' to extinction.

MacKenzie and Norval (1980) experimentally transmitted E. ruminantium to sheep by means of $A$. tholloni nymphs that had been fed as larvae on an infected sheep, and by adult ticks that had been fed as nymphs on infected sheep. Because of their preference for elephants, the adults of A. tholloni are unlikely to play a role in the transmission of E. ruminantium in the field. In addition, elephants and domestic livestock very rarely share the same habitat, thus free-living $A$. tholloni questing for hosts are unlikely to be present in the absence of elephants. However, MacKenzie and Norval (1980) reported 
that cattle, sheep and goats at the Rekomitji Research Station situated in a game reserve in the Zambezi Valley of Zimbabwe were frequently infested with $A$. tholloni larvae and nymphs and that cases of heartwater were recorded in domestic livestock at the research station in the absence of any of the known vectors.

\section{Amblyomma variegatum}

The geographical distribution of $A$. variegatum includes north-western Zimbabwe, the Zambezi Strip in north-eastern Namibia, much of Zambia and thence northwards into subSaharan Africa (Walker \& Olwage 1987). Adult ticks prefer cattle as well as large wild herbivores as hosts, while the immature stages infest the same hosts as the adults, and also hares and the larger species of ground-feeding birds (Petney, Horak \& Rechav 1987; Theiler 1962). Theiler (1962) reports adult ticks on white and black rhinoceroses, while Walker (1974) records collections from five of 54 black rhinoceroses in Kenya. The large proportion of black rhinoceroses infested with $A$. variegatum in Zambia suggests that these animals are amongst the preferred hosts for adult ticks. Amblyomma variegatum is an effective vector of E. ruminantium (Norval \& Horak 2004) and also of R. africae (Kelly 2001).

\section{Cosmiomma hippopotamensis}

Joseph Burke, a British naturalist made the first ever collection of $C$. hippopotamensis from a rhinoceros or a hippopotamus about $20 \mathrm{~km}$ to the north-west of Pretoria in 1840, and a male tick and female tick from this collection were described by Denny in 1843. No collections have been made in South Africa since then (Apanaskevich et al. 2013). In Namibia, Bezuidenhout and Schneider (1972) made the last recorded collections of C. hippopotamensis in Kaokoland in the north-west of the country in 1971. They collected 114 adult ticks from vegetation along footpaths used by rhinoceroses to get to water and successfully fed some of these ticks on a rhinoceros calf. One of the three female ticks that engorged on the calf laid a large batch of fertile eggs from which larvae hatched and these were used in studies to determine the life cycle of the tick (Apanaskevich et al. 2013). The translocation of rhinos from Kaokoland to the Etosha National Park and settlement of humans in the north-west of the country has probably contributed to the disappearance of C. hippopotamensis in Namibia. We think it is now extinct in both South Africa and Namibia, and perhaps in Africa. In their review of ixodid tick species coendangered with their hosts, Mihalca et al. (2011) consider C. hippopotamensis' status as 'vulnerable'.

\section{Dermacentor rhinocerinus}

Only two of the 35 Dermacentor species that occur worldwide are present in the Afrotropical region, Dermacentor circumguttatus and D. rhinocerinus (Guglielmone et al. 2014). The adults of D. circumguttatus prefer elephants as hosts and those of $D$. rhinocerinus prefer white and black rhinoceroses (Guglielmone et al. 2014; Knapp et al. 1997). Dermacentor rhinocerinus was first described by Denny in 1843 from a male specimen collected from a black rhinoceros in South Africa (Keirans 1993). Dermacentor rhinocerinus is widespread in Africa, but as rhino populations decrease or disappear because of poaching, its distribution range is diminishing (Keirans 1993). Mihalca et al. (2011) consider D. rhinocerinus to be 'critically endangered' should black rhinos be its only hosts, and 'near threatened' on white rhinos.

With the possible exception of pockets in north-eastern KwaZulu-Natal, D. rhinocerinus, with its rhino hosts, had probably become extinct in the rest of South Africa, including the region now known as the Kruger National Park, by the end of the 19th and beginning of the 20th centuries. We believe that $D$. rhinocerinus has been re-introduced into the Kruger National Park with rhinoceroses from the KwaZuluNatal parks (Braack et al. 1995). Its prevalence on rhinos in the park and surrounding conservancies now appears to be greater than that in the KwaZulu-Natal nature reserves. The larvae and nymphs of $D$. rhinocerinus feed on rodents (Horak \& Cohen 2001), for which they probably quest from the soil surface or from the base of tufts of grass. The brightly coloured questing adult ticks are commonly encountered high up on thick grass stems along the verges of roads and game paths, wherever there are dense populations of rhinos in the Kruger National Park.

Since 1933, when it was collected from a black rhinoceros at Grootfontein, no collections of D. rhinocerinus have been made in Namibia (Walker 1991). We now consider it to be extinct there. During the 1970's and 80's D. rhinocerinus was present in the south-east and south-west of Zimbabwe and at several localities in the Zambezi Valley in the north-west of the country (Duncan 1989; Norval \& Colborne 1985). This may no longer be true after the poaching and consequent precautionary translocation of rhinoceroses that has taken place. None of the 30 rhinoceroses examined in south-eastern Zimbabwe in the present study, were infested. Although D. rhinocerinus was not present amongst the ticks collected from rhinos in Zambia, it has previously been reported as occurring there (Keirans 1993).

\section{Hyalomma glabrum}

Hyalomma glabrum, previously referred to as Hyalomma marginatum turanicum, was reinstated as a valid species by Apanaskevich and Horak (2006). It is the most colourful of the three Hyalomma species that occur in South Africa. In addition to the ivory coloured band that encircles the distal margin of each segment of its legs, the dorsal surface of each segment is coated with a strip of ivory coloured enamelling. This is especially distinct on the segments of the hind legs. Hyalomma glabrum is a strictly South African tick and is the only Hyalomma sp. whose distribution is confined to the southern hemisphere. It is present in Nama Karoo and Succulent Karoo Biomes in the Eastern, Western and Northern Cape provinces (Apanaskevich \& Horak 2006). It would seem that $H$. glabrum and $H$. rufipes are mutually exclusive in their habitat preferences. 
The adults of H. glabrum have a preference for large herbivores and large numbers have been collected from Cape mountain zebras and especially eland in the Mountain Zebra National Park. Its immature stages have been collected from scrub hares and birds in the park (Horak et al. 1991a). The presence of adult ticks on black rhinoceroses after their re-introduction into the Mountain Zebra National Park and the Karoo National Park more than a century after their disappearance in the Karoo is thus not unexpected. The collections from black rhinoceroses are first records on these animals.

\section{Hyalomma rufipes}

Hyalomma rufipes is a drought-tolerant species and with the exception of the north-eastern regions of Mpumalanga and Limpopo provinces, the eastern regions of KwaZulu-Natal, the eastern Free State and the southern regions of the Western Cape province, it is present throughout South Africa (Spickett 2013). In agreement with this pattern of distribution, no $H$. rufipes were collected from rhinoceroses in the Kruger National Park and surrounding conservancies, nor in the north-eastern parks of KwaZulu-Natal. Hyalomma rufipes was replaced by $H$. glabrum in the Karoo and their occurrence seems to be mutually exclusive (Figure 1). Hyalomma rufipes was the predominant species in the central and western Free State and Northern Cape province, and was present on black rhinos in all three regions in which collections were made in Namibia.

The preferred hosts of the adults of $H$. rufipes are large domestic and wild ruminants, particularly cattle, giraffes and eland (Dreyer, Fourie \& Kok 1998; Horak et al. 2007), while the immature stages infest Cape hares, scrub hares and birds (Horak \& Fourie 1991; Van Niekerk, Fourie \& Horak 2006). It was the second most prevalent species collected from rhinos in southern Africa in the present study (Figure 1), and rhinos must be considered as one of the preferred hosts of adult $H$. rufipes.

Hyalomma rufipes is a vector of Babesia occultans, the causative organism of benign babesiosis in cattle, with infection passing transovarially from one generation of adults to the next (Gray \& De Vos 1981). It is also the most effective vector in South Africa of the virus causing Crimean-Congo haemorrhagic fever in humans (Swanepoel et al. 1983).

\section{Hyalomma truncatum}

Hyalomma trunctum is a drought-tolerant species and is absent in the moist eastern as well as the colder Highveld regions of South Africa (Spickett 2013). It is the only species that was collected in every region in which rhinos were examined (Figure 1). A large number of collections were made from rhinos in the Free State and Northern Cape provinces, it was the only Hyalomma species collected from rhinos in the Kruger National Park and the predominant species on animals in the Etosha National Park.

The adults of $H$. truncatum prefer large herbivores as hosts and large numbers have been collected from giraffes and eland (Horak et al. 2007), while the immature stages infest Cape hares, scrub hares and murid rodents (Horak \& Fourie 1991; Horak et al. 1991a). Judging by the large number of rhinos that were infested and that ticks were present on them in every region included in the present study, rhinos must be considered as one of the preferred hosts of the adults of H. truncatum.

Hyalomma truncatum is a vector of Babesia caballi, the cause of equine piroplasmosis, with infection passing transovarially from one generation of adults to the next. The females also produce an epitheliotrophic toxin responsible for sweating sickness in calves (Norval \& Horak 2004).

\section{Rhipicephalus species}

The ticks, $R$. follis, $R$. gertrudae and $R$. simus, are similar in appearance but the denseness of punctations on the conscuta of the males and scuta of the females varies (Walker, Keirans \& Horak 2000). Although there is some overlap, their geographical distributions differ (Walker et al. 2000). Rhipicephalus follis is moderately punctate and is associated with mountainous terrain mainly east of longitude $24^{\circ}$. Rhipicephalus gertrudae is heavily punctate and is present in drier regions west of this longitude and in the winter rainfall regions of the Western and Northern Cape provinces where summers are hot and dry. It is also present in Namibia. But for four irregular rows of large punctations, the conscutum of $R$. simus males is smooth. It is widespread in the northern, eastern and south-eastern regions of South Africa. The collections made from rhinoceroses in the various regions reflect the distributions of these three ticks. All of them prefer monogastric animals such as zebras, warthogs and now also rhinoceroses, as well as the larger carnivores as hosts, but buffaloes, elands and cattle may also be infested (Horak et al. 2007). Their larvae and nymphs prefer murid rodents as hosts (Walker et al. 2000).

A single collection of $R$. longiceps was made from a black rhinoceros in Namibia. It is the only Rhipicephalus species, which, relative to its size, has long mouthparts (Walker et al. 2000). Its distribution is confined to Namibia and Angola and in total very few collections have been made (Walker et al. 2000). These collections include ticks from warthogs and a giraffe and now also a rhinoceros (Horak et al. 1992; Horak et al. 1983).

Rhipicephalus maculatus is the only ornate Rhipicephalus species present in southern Africa. It is present in a broad strip of coastal mosaic vegetation and adjacent woodlands from Durban in KwaZulu-Natal northwards to Somalia (Walker et al. 2000). It has short but sturdy mouthparts and its preferred hosts are large mammals with thick hides, such as elephants, rhinoceroses, warthogs, bushpigs and buffaloes (Baker \& Keep 1970; Horak, Boomker \& Flamand 1991b; Horak et al. 2007; Walker et al. 2000). Several of these animals do not have dense hair-coats and hence ticks with short mouthparts are prone to be removed by grooming or predation by red-billed oxpeckers, Buphagus erythrorhyncus (Bezuidenhout \& Stutterheim 1980). 
Infestation of rhinos with $R$. appendiculatus nymphs and with $R$. eversti eversi adults should be regarded as incidental. Rhipicephalus neumanni occurs in the drier western regions of South Africa and in southern Namibia (Walker et al. 2000), and both animals that were infested were sampled in the Northern Cape province. Rhipicephalus zumpti is a rather rare species and is present in coastal woodland and adjacent regions in KwaZulu-Natal and the Eastern Cape province (Walker et al. 2000). It also seems to have a preference for monogastric mammals and fairly large numbers have been collected from bushpigs in north-eastern KwaZulu-Natal (Horak et al. 1991b) and now three males from two black rhinoceroses in the Eastern Cape province.

\section{General}

Although fewer black than white rhinoceroses were sampled for ticks, they were examined in more geographic regions and hence a greater number of tick species were recovered from them. Those in Zambia alone harboured three species not collected elsewhere. The central and south eastern region of Limpopo province combined with northern Gauteng constituting the central northern provinces, was the most species-rich with seven species collected from rhinos.

Most of the ticks that were collected from rhinos in the present study are characterised by one or two features; they are ornate and/or have long or sturdy mouthparts. All the Amblyomma spp. collected from the rhinos are ornate and have long mouthparts. Their long mouthparts not only ensure a sturdy hold-fast on the thick hides of their hosts but also have the advantage of making them less prone to being removed by grooming or to predation by oxpeckers because of the difficulty with which they are dislodged. Their ornamentation possibly alerts oxpeckers to the fact that they will be difficult to remove. Dermacentor rhinocerinus is ornate and has medium length, sturdy mouthparts. The three Hyalomma spp. have long mouthparts and the legs of $H$. glabrum are ornate. Rhipicephalus longiceps has long mouthparts and $R$. maculatus is ornate and has short but sturdy mouthparts. Moreover, R. maculatus adults probably escape severe predation by attaching amongst the Amblyomma spp. on the ventral aspects of their hosts' bodies. In addition, the colouration on the scuta of $R$. maculatus females mimics that of A. hebraeum females. Rhipicephalus follis, R. gertrudae and $R$. simus have short mouthparts, but with H. truncatum, attach to the tail and its tip within the tailbrush.

\section{Conclusion}

The ticks that infest rhinoceroses in southern Africa are generally ornate and have long or robust mouthparts. These comprise six Amblyomma species and D. rhinocerinus, $H$. glabrum and R. maculatus, as well as the now possibly extinct species Cosmiomma hippotamensis. Amongst these ticks A. rhinocerotis is in danger of extinction in South Africa, while $D$. rhinocerinus is likely to survive in the north-eastern regions of the country for as long as rhinoceroses are also present. The only species that was present in all ten regions in which ticks were collected was $H$. truncatum, followed by H. rufipes in seven regions. The latter two species and A. hebraeum and A. variegatum are important vectors of disease to domestic livestock.

\section{Acknowledgements}

We express our gratitude to all the technicians, rangers, wardens and nature reserve managers, who assisted with tick collections and to Dylan Smith who assisted with collections in the Northern Cape province and Ortwin Aschenborn who collected ticks from rhinos in the Hardap Nature Reserve in Namibia. We are also grateful to SANParks and the Provincial Nature reserve authorities as well as private institutions and individuals for granting permission to make collections from rhinos in the reserves under their control. The participation of the senior author in the project was funded by a grant from the National Research Foundation.

\section{Competing interests}

The authors declare that they have no financial or personal relationships which may have inappropriately influenced them in writing this article.

\section{Authors' contributions}

I.G.H. was the project leader, identified all the ticks and was responsible for writing the first and final drafts of the manuscript. C.R.B., D.G., G.H. and M.H. collected ticks from rhinos in the Kruger National Park and its surrounds. M.H. also collected ticks from rhinos in North West province and assisted D.S. with the collection of ticks in Zambia. D.V.C. collected ticks in KwaZulu-Natal, D.P. and D.Z. collected ticks in the Eastern Cape province, P.J.N. collected ticks in the Free State, D.N.M. collected ticks in the Northern Cape province, C.M.F. collected ticks in Zimbabwe and J.W.K. collected ticks from rhinos in Namibia. A.H. reviewed the data for possible statistical analysis. All authors read and approved the manuscript.

\section{References}

Apanaskevich, D.A. \& Horak, I.G., 2006, 'The genus Hyalomma Koch, 1844. I. Reinstatement of Hyalomma (Euhyalomma) glabrum Delpy, 1949 (Acari, Ixodidae) as a valid species with a redescription of the adults, the first description of its as a valid species with a redescription of the adults, the first description of its
immature stages and notes on its biology', Onderstepoort Journal of Veterinary immature stages and notes on its biology', Onderstepoort Jo
Research 73, 1-12. https://dx.doi.org/10.4102/ojvr.v73i1.164

Apanaskevich, D.A., Walker, J.B., Heyne, H., Bezuidenhout J.D. \& Horak, I.G., 2013 , 'First description of the immature stages and redescription of the adults of ' Cosmiomma hippopotamensis (Acari: Ixodidae) with notes on its bionomics', Cosmiomma hippopotamensis (Acari: Ixodidae) with notes on its bionomics',
Journal of Medical Entomology 50, 709-722. https://dx.doi.org/10.1603/ME12271

Baker, M.K. \& Keep, M.E., 1970, 'Checklist of the ticks found on the larger game animals in the Natal game reserves', Lammergeyer 12, 41-47.

Bezuidenhout, D.J. \& Schneider, H.P., 1972, 'Studies on the biology of Cosmiomma hippopotamensis Denny, 1843 in South West Africa', Journal of the South African Veterinary Medical Association 43, 301-304.

Bezuidenhout, J.D. \& Stutterheim, C.J., 1980, 'A critical evaluation of the role played by the red-billed oxpecker Buphagus erythrorhynchus in the biological control of ticks', Onderstepoort Journal of Veterinary Research 47, 51-75.

Braack, L.E.O., Maggs, K.A.R., Zeller, D.A. \& Horak, I.G., 1995, 'Exotic arthropods in the Kruger National Park, South Africa: Modes of entry and population status', African Entomology 3, 39-48.

Cumming D.H., Du Toit, R.F. \& Stuart, S.N., 1990, African Elephants and Rhinos: Status survey and conservation action plan, IUCN, Gland. 
Dower, K.M., Petney, T.N. \& Horak, I.G., 1988, 'The developmental success of Amblyomma hebraeum and Amblyomma marmoreum on the leopard tortoise, Geochelone pardalis', Onderstepoort Journal of Veterinary Research 55 , 11-13.

Dreyer, K., Fourie, L.J. \& Kok, D.J., 1998, 'Tick diversity, abundance and seasonal dynamics in a resource-poor urban environment in the Free State Province', Onderstepoort Journal of Veterinary Research 65, 305-316.

Duncan, I.M., 1989, 'The use of flumethrin pour-on for de-ticking black rhinoceros (Diceros bicornis) prior to translocation in Zimbabwe', Journal of the South African Veterinary Association 60, 195-197.

Gray, J.S. \& De Vos, A.J., 1981, 'Studies on a bovine Babesia transmitted by Hyalomma marginatum rufipes Koch, 1844', Onderstepoort Journal of Veterinary Research 48, 215-223.

Guglielmone, A., Robbins, R.G., Apanaskevich, D.A., Petney, T.N., Estrada-Peña, A. \& Horak, I.G., 2014, The hard ticks of the world (Acari: Ixodida: Ixodidae), Springer, Dordrecht, $738 \mathrm{pp}$.

Horak, I.G., Anthonissen, M., Krecek, R.C. \& Boomker, J., 1992, 'Arthropod parasites of springbok, gemsbok, kudus, giraffes and Burchell's and Hartmann's zebras in the Etosha and Hardap Nature Reserves, Namibia', Onderstepoort Journal of Veterinary Research 59, 253-257.

Horak, I.G., Biggs, H.C., Hanssen, T.S. \& Hanssen, R.E., 1983, 'The prevalence of helminth and arthropod parasites of warthog, Phacochoerus aethiopicus, in South West Africa/Namibia', Onderstepoort Journal of Veterinary Research 50, 145-148.

Horak, I.G., Boomker, J. \& Flamand, J.R.B., 1991b, 'Ixodid ticks and lice infesting red duikers and bushpigs in north-eastern Natal', Onderstepoort Journal of Veterinary Research 58, 281-284.

Horak, I.G. \& Cohen, M., 2001, 'Hosts of the immature stages of the rhinoceros tick, Dermacentor rhinocerinus (Acari, Ixodidae)', Onderstepoort Journal of Veterinary Research 68, 75-77.

Horak, I.G. \& Fourie, L.J., 1991, 'Parasites of domestic and wild animals in South Africa. XXIX. Ixodid ticks on hares in the Cape Province and on hares and red rock rabbits in the Orange Free State', Onderstepoort Journal of Veterinary Research 58 , 261-270.

Horak, I.G., Fourie, L.J., Novellie, P.A. \& Williams, E.J., 1991a, 'Parasites of domestic and wild animals in South Africa. XXVI. The mosaic of ixodid tick infestations on birds and mammals in the Mountain Zebra National Park', Onderstepoort Journal of Veterinary Research 58, 125-136.

Horak, I.G., Golezardy, H. \& Uys, A.C., 2007, 'Ticks associated with the three largest wild ruminant species in southern Africa', Onderstepoort Journal of Veterinary Research 74, 231-242. https://dx.doi.org/10.4102/ojvr.v74i3.126

Horak, I.G., Jordaan, A.J., Nel, P.J., Van Heerden, J., Heyne, H. \& Van Dalen, E.M., 2015 'Wildlife translocation: Implications for disease and the introduction of foreign tick species into Free State Province, South Africa', Journal of the South African Veterinary Association 86(1), Art. \#1255, 9 pages. https://dx.doi.org/10.4102/ jsava.v86i1.1255

Horak, I.G., Maclvor, K.M. De F., Petney, T.N. \& De Vos, V., 1987, 'Some avian and mammalian hosts of Amblyomma hebraeum and Amblyomma marmoreum (Acari: Ixodidae)', Onderstepoort Journal of Veterinary Research 54, 397-403.

Keirans, J.E., 1993, 'Dermacentor rhinocerinus (Denny, 1843) (Acari: Ixodida: Ixodidae) Redescription of the male, female and nymph and first description of the larva' Onderstepoort Journal of Veterinary Research 60, 59-68.

Kelly, P.J., 2001, 'Amblyomma hebraeum is a vector of Rickettsia africae and not $R$. conorii', Journal of the South African Veterinary Association $72,182 . \mathrm{https}: / / \mathrm{dx}$ doi.org/10.4102/jsava.v72i4.649
Knapp, S.E., Krecek, R.C., Horak, I.G. \& Penzhorn, B.L., 1997, 'Helminths and arthropods of black and white rhinoceroses in southern Africa', Journal of Wildlife Diseases 33, 492-502. https://dx.doi.org/10.7589/0090-3558-33.3.492

Knight, M.H., Balfour, D. \& Emslie, R.H., 2013, 'Biodiversity management plan for the black rhinoceros (Diceros bicornis) in South Africa 2011-2020', South African Government Gazette, No. 36096, South Africa.

MacKenzie, P.K.I. \& Norval, R.A.I., 1980, 'The transmission of Cowdria ruminantium by Amblyomma tholloni, Veterinary Parasitology 7, 265-268. https://dx.doi. org/10.1016/0304-4017(80)90030-8

Mihalca, A.D., Gherman, C.M. \& Cosma, V., 2011, 'Coendangered hard-ticks; threatened or threatening?', Parasites \& Vectors 4, 71. https://dx.doi. org/10.1186/1756-3305-4-71

Norval, R.A.I., 1983, 'The ticks of Zimbabwe. VII. The genus Amblyomma', Zimbabwe Veterinary Journal 14, 3-18.

Norval, R.A.I. \& Colborne, J., 1985, 'The ticks of Zimbabwe. X. The genera Dermacentor and Rhipicentor', Zimbabwe Veterinary Journal 16, 1-4.

Norval, R.A.I. \& Horak, I.G., 2004, 'Vectors: Ticks', in J.A.W. Coetzer \& R.C. Tustin (eds.), Infectious diseases of livestock, 2nd edn., pp. 3-42, Oxford University Press, Cape Town.

Norval, R.A.I. \& MacKenzie P.K.I., 1981, 'The transmission of Cowdria ruminantium by Amblyomma sparsum', Veterinary Parasitology 8, 189-191. https://dx.doi. org/10.1016/0304-4017(81)90047-9

Petney, T.N., Horak, I.G. \& Rechav, Y., 1987, 'The ecology of the African vectors of heartwater, with particular reference to Amblyomma hebraeum and Amblyomma variegatum', Onderstepoort Journal of Veterinary Research 54, 381-395.

Skinner, J.D. \& Chimimba, T.C., 2005, The Mammals of the Southern African Subregion, 3rd edn., Cambridge University Press, Cambridge, pp. 527-537.

Spickett, A.M., 2013, Ixodid ticks of major economic importance and their distribution in South Africa, Agri Connect (Pty) Ltd., Pretoria, 79 pp.

Swanepoel, R., Struthers, J.K., Shepherd, A.J., McGillivray, G.M., Nel, M.J. \& Jupp, P.G., 1983, 'Crimean-Congo hemorrhagic fever in South Africa', American Journal of Tropical Medicine and Hygiene 32, 1407-1415.

Theiler, G., 1962, The Ixodoidea parasites of vertebrates in Africa south of the Sahara (Ethiopian region), Project S 9958. Report to the Director of Veterinary Services, Onderstepoort, Mimeographed.

Theiler, G. \& Salisbury, L.E., 1959, 'Ticks in the South African Zoological Survey Collection - Part IX - "The Amblyomma marmoreum group", Onderstepoort Journal of Veterinary Research 28, 47-124.

Van Niekerk, J., Fourie, L.J. \& Horak, I.G., 2006, 'Birds as hosts of immature ixodid ticks in Free State Province, South Africa', Onderstepoort Journal of Veterinary Research 73, 123-130. https://dx.doi.org/10.4102/ojvr.v73i2.157

Walker, J.B., 1974, 'The ixodid ticks of Kenya. A review of present knowledge of their hosts and distribution', Commonwealth Institute of Entomology, London.

Walker, J.B, 1991, 'A review of the ixodid ticks (Acari, Ixodidae) occurring in southern Africa', Onderstepoort Journal of Veterinary Research 58, 81-105.

Walker, J.B., Keirans, J.E. \& Horak, I.G., 2000, The genus Rhipicephalus (Acari, Ixodidae): A guide to the brown ticks of the World, Cambridge University Press, Cambridge.

Walker, J.B. \& Olwage, A., 1987, 'The tick vectors of Cowdria ruminantium (Ixodoidea, Ixodidae, genus Amblyomma) and their distribution', Onderstepoort Journal of Veterinary Research 54, 353-379.

Yeoman, G.H. \& Walker, J.B., 1967, The ixodid ticks of Tanzania. A study of the zoogeography of the Ixodidae of an east African country, Commonwealth Institute of Entomology, London. 